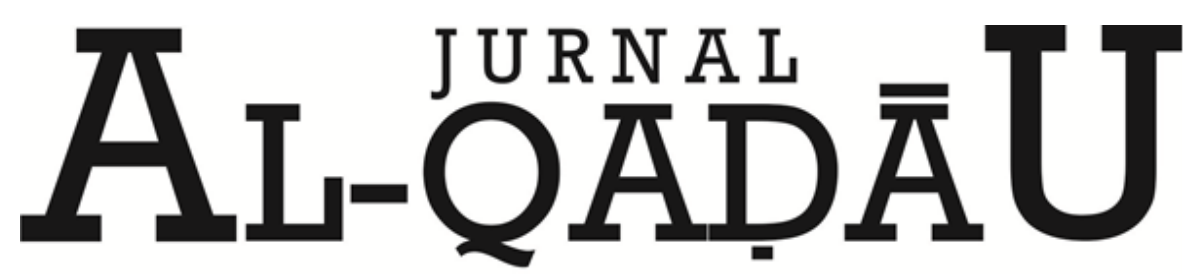

PERADILAN dan HUKUM KELUARGA ISLAM

\title{
Hubungan Islam-Kristen (Abad Pertengahan hingga Modern)
}

The Relations between Islam and Christian (Middle to Modern Ages)

Subehan Khalik

Dosen Fakultas Syariah dan Hukum UIN Alauddin Makassar

Email: subehank1@gmail.com

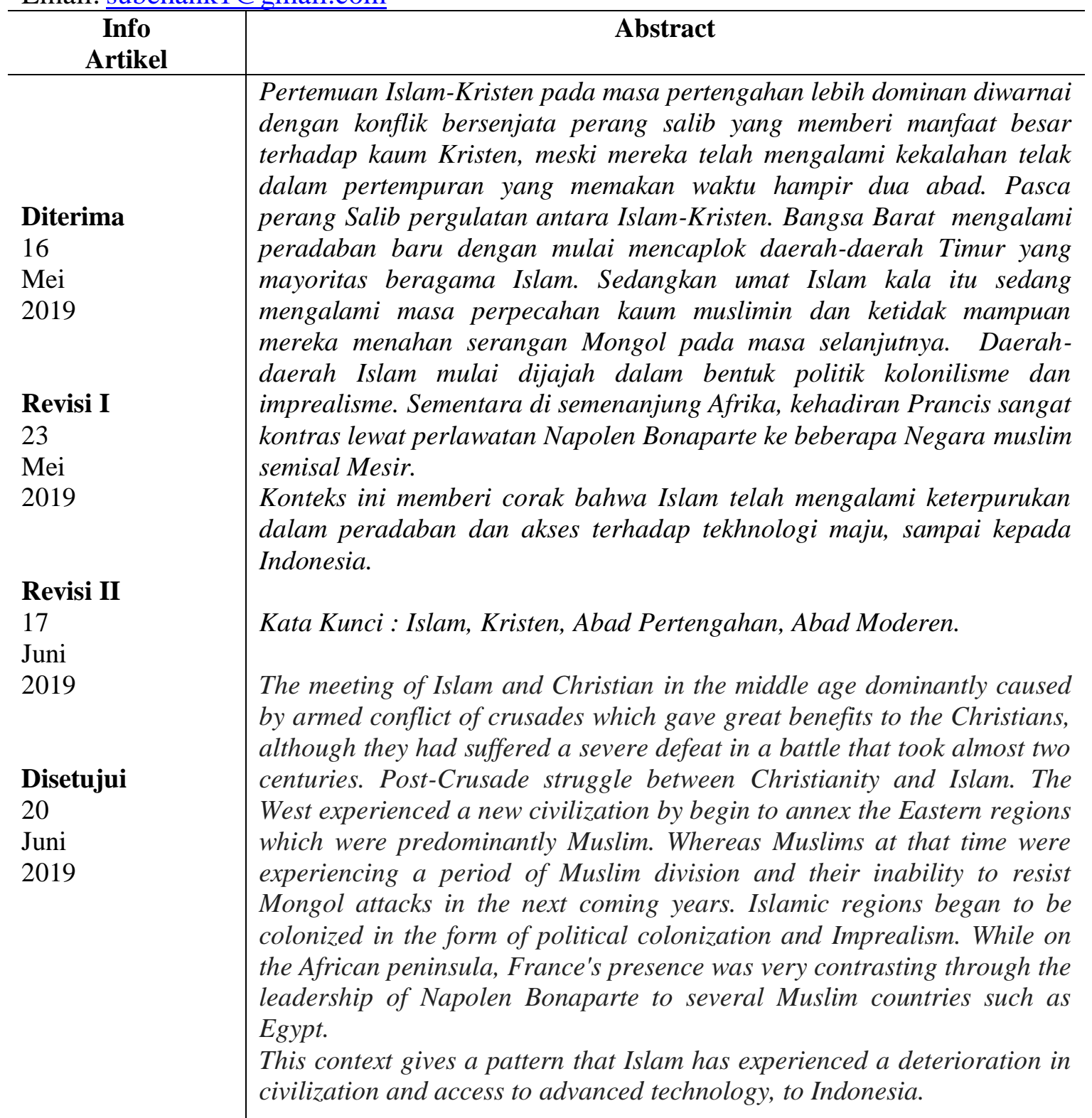

Keywords: Islam, Christianity, Middle Ages. 


\section{A. PENDAHULUAN}

Islam dan Kristen adalah dua agama samawi yang memiliki akar sejarah yang saling berkaitan. Keberkaitan antara dua agama ini tidak hanya terjadi pada sejarah turun keduanya, akan tetapi juga terjadi pada persentuhannya pada masa Rasulullah saw. hingga zaman pertengahan, bahkan hingga saat ini. Kontak sejarah agama Islam dengan agama Kristen telah melahirkan rentang sejarah kelabu dalam proses penyebaran agama dan fungsi agama sebagai sumber kebudayaan. Islam dan Kristen terdistorsi pada sebuah kericuhan dan berakhir dengan perang. Perang ini melahirkan berbagai cerita seputar gilang-gemilang panglima terkemuka mereka dalam menaklukkan daerah masing-masing.

Geneologi Islam dan Kristen selaku agama langit bertemu pada Nabiullah Ibrahim as. Meski demikian, terjadi bibit perpecahan antara keduanya pada akar teologi. Islam yang mengklaim bahwa ajaran agama Kristen telah mengalami perubahan dan tidak murni lagi. Pada saatnya teologi ini kemudian memberi simpulan bahwa kedatangan Islam adalah dalam rangka memperbaiki ketidak sempurnaan tadi. ${ }^{1}$ Pada sisi lain kaum Kristiani merasa semakin terpojok oleh semangat penyebaran agama yang dilakukan oleh kaum Muslimin.

Konflik yang berakar pada sejarah teologi ternyata tidak berakhir dalam kurun waktu yang pendek. Pertikaian ini terus berlanjut hingga saat ini dalam simbol perang idiologi dan terkadang pula dalam medan perang yang bernama "perang salib". Maka penelitian akan mengurai secara mendalam bagaimana hubungan Islam-Kristen zaman pertengan hingga modern yang diawali latar belakang pergolakan Islam-Kristen, selanjutnya bentuk keterhubungan antara Islam-Kristen di zaman pertengahan dan bentuk keterhubungan Islam-Kristen pada zaman modern.

\section{B. METODE PENELITIAN}

Penelitian ini menggunakan metode penelitian historis atau metode sejarah yakni interspretasi terhadap suatu masa untuk memahami kenyataan sejarah. Proses pengumpulan data dengan mengumpulkan sumber-sumber atau data-data yang diperlukan, difokuskan pada dokumen, literatur ilmiah, maupun tulisan lain yang terkait materi hubungan Islam-Kristen (abad pertengahan hingga modern). Selanjutnya mengkritisi dengan menyeleksi sumber sejarah yang telah didapatkan. Melakukan interpretasi data-data dalam bentuk konsep berdasarkan analisis terhadap sumber sejarah yang telah diperoleh.

Data yang diperoleh selama proses penelitian, selanjutnya dianalisis dengan langkah-langkah sebagai berikut reduksi data, penyajian data dan verifikasi data. Dianalisis secara kualitatif kemudian disajikan secara deskriptif yaitu menguraikan, menggambarkan, dan menjelaskan sesuai dengan permasalahan yang erat kaitannya dengan penelitian ini.

\footnotetext{
${ }^{1}$ Azyumardi Azra, Pergolakan Politik Islam: Dari Fundamentalisme, Modernisme hingga PostModernisme, (Jakarta: Paramadina, 1996), h. 60; Azyumardi Azra, Memahami Konflik barat-Islam dalam Era Globalisasi, Pengantar dalam Buku Karel Strenbrink, Kawan Dalam Pertikaian, Kaum Kolonial Belanda dan Islam di Indonesia, (Bandung: Mizan, 1995), h. vii.
} 


\section{PEMBAHASAN}

\section{Akar Pergolakan Islam-Kristen}

Rasulullaw saw. mendirikan Negara Madinah telah menjadikan Islam sebagai agama berkembang pesat hingga ke penjuru dunia. Persentuhan pertama Islam dengan kaum Kristen dimulai ketika Rasulullah saw mengirim utusan untuk menyampaikan surat tentang ajakan bagi Herklius untuk masuk Islam. Romawi kala itu banyak dihuni oleh bangsa Arab beragama Kristen. ${ }^{2}$

Pasca wafatnya Rasulullah saw. para sahabat melebarkan sayap kekuasaan Negara Madinah keluar jazirah Arab di bawah pimpinan Khalid bin Walid dan dapat menaklukkan Persia. Langkah penaklukan selanjutnya mengarah ke Utara dan untuk kesekian kalinya wilayah Romawi, Suria dan Palestina mampu ditaklukkan. ${ }^{3}$

Selanjutnya terjadi intensitas yang tinggi dalam percaturan antara Islam dan Kristen sebagai idiologi. Pergulatan kedua agama besar ini dilandasi oleh ajaran dasar bahwa keduanya merupakan agama transnasional. ${ }^{4}$ Kristem menghadapi situasi dimana umat Islam semakin kuat menyebarkan agama mereka dan melahap daerah umat Kristiani. Ajaran Islam telah mampu memasuki daerah Kristen di laut tengah-dari Anatolia menembus Giblaltar hingga Spanyol. ${ }^{5}$

Umat Kristiani pada sisi lain semakin cemas dengan gerakan kaum Muslimin melebarkan sayap kekuasaan mereka. Meskipun secara factual daerah-daerah yang ditaklukkan oleh kaum muslimin masih tetap pada agama awal mereka. Dalam ajaran Islam, kelompok minoritas (żimmī) atau kelompok yang terlingdungi (musta'mīn) tidak akan tersentuh dalam perpindahan agama mereka dan sebagai balasan dari jaminan tersebut, kedua kelompok ini diwaibkan membayar jizyah.

Puncak pergumulan Islam-Kristen pada masa selanjutnya melahirkan sebuah peristiwa yang memiriskan yang kita kenal dengan perang salib. ${ }^{6}$ Peristiwa kontra kemanusiaan ini berlansung cukup lama dan bahkan sebagian menyimpulkan jika perang ini belum kunjung berakhir hingga saat ini.

\section{Islam-Kristen pada masa Pertengahan}

Mengawali patra tulisan ini, akan dibahas terlebih dahulu periodesasi sejarah masa pertengahan. Dalam pandangan Ahmad M. Sewang, periodesasi sejarah mutlak ada dan selalu mengikuti tempat dan waktu. Runtut peristiwa diurut berdasar waktu dan peristiwa berdasar aktivitas manusia. ${ }^{7}$ Tulisan ini selanjutnya akan mengikuti pendapat Harun Nasution yang membagi periodesasi tersebut menjadi :

1. Periode Klasik (tahun 650-1000 M)

2. Periode Disintrgrasi (1000-1250 M)

\footnotetext{
${ }^{2}$ Șafiyyu al-Raḥmān al-Mubarakfīrī, Sirah Nabawiyah, Terjemahan Kathur Suhardi, (Jakarta: Pustaka al-Kaustar, 1997), h. 463-466.

${ }^{3}$ Badri Yatim, "Dari Mekkah ke Madinah” Dalam Taufik Abdullah dan Din Syamsuddin (ed), Ensiklopedia Tematis Dunia Islam, jilid II, (Jakarta: PT. Ichtiar Van Hoeve, t.t.), h. 24.

${ }^{4}$ John L. Esposito, Bahaya Hijau, Alihbahasa Sunarto, (Jogjakarta: Pustaka Pelajar, 1997), h. 62.

${ }^{5}$ Azyumardi Azra, Pergolakan Politik Islam: Dari Fundamentalisme, Modernisme hingga PostModernisme, h. 60.

${ }^{6}$ Muhammad Fārid Wajd̄̄, Da'irah al-Ma'ārif al-Qarn al- 'Isyrīn, Jilid V, (Beyrīt: Dār al-Fikr, t.t.), h. 531; Tim Penyusun IAIN Syarif Hidayatullah, Ensiklopedia Islam (Jakarta: Djambatan, 1992), h. $837-838$

${ }^{7}$ Ahmad M. Sewang, Islamisasi Kerajaan Gowa; Abad XVI sampai Abad XVII (Jakarta: Yayasan Obor Indonesia, 2005), h. 5
} 
3. Pertengahan (tahun $1250-1800 \mathrm{M}$ )

4. Tiga Kerajaan Besar (tahun 1500-1800 M)

5. Moderen (tahun 1800-sekarang). ${ }^{8}$

Peristiwa monumental yang mengikat Islam-Kriten pada ikatan emosional yang tinggi adalah "Perang Salib". Telah disinggung pada bagian awal tulisan ini bahwa akar masalah musibah kemanusia ini adalah factor donimasi dan kecurigaan masing-masing penganut. Peristiwa perang salib pertamakali dikumandangkan pada tanggal 20 November 1095 saat Paus Urbanus II dalam rapat dewan gereja memutuskan melawan umat Islam yang saat itu melancarkan ekspansi ke wilayah kekuasaan Alexus Cowneus di Asia. Permintaan Alexus Cowneus untuk melibatkan umat Kristiani dalam perang yang sementara dialaminya disahuti oleh Paus Urbanus II, maka terjadilah musibah kemanusiaan yang berlansung sebanyak delapan periode dari tahun 1095-1244 M. ${ }^{9}$ Paus Urbanus sangat termotivasi untuk melancarkan serangan kepada kaum muslim di Timur karena motivasi ingin menyatukan keUskupan Agung di Barat dengan kepemimpinan tertinggi gereja Orthodox di Timur. Secara kronologis, perang salib melewati tujuh fase sebagai berikut :

1. Tahun 1050 di Sisilia, orang-orang Islam diusir dari daerah ini dan tak berapa lama kemudian tepatnya tahun 1063, tentara salib Prancis dan Spanyol sepakat untuk merebut kembali daerah-daerah kekuasaan Islam. Tentara salib berhasil menguasai daerah Antiokhia kemudian meneruskan perjalanan mereka ke Yerusalem dan menguasainya setelah mengepung daerah ini sekian lama. Tahun 1099-1187 kaum salib mendirikan kerajaan Kristen di Yerusalem yang wilayah kekuasaannya meliputi; Antiokhia, Edessa dan Tripoli. Secara pemerintahan, daerah ini I bawah kekuasaan Konstantinopel, namun gerejanya di bawah kekuasaan Paus di Roma. Kekalahan kaum muslimin pada perang kali ini lebih disebabkan oleh kelemahan umat Islam akibat wafatnya pemimpin Turki Saljuk yang bernama Malik Syah. ${ }^{10}$

2. Berlansung dari tahun (1147-1149), pada priode ini kemenangan ada di tangan kaum Muslimin setelah Nuruddin Zanki yang menggantikan ayahnya menjadi pemimpin Turki Saljuk. Nuruddin Zanki mampu memadamkan propaganda perang salin yang dilaksanakan oleh Bernard Clairvux. Pemimpin tentara salib kala itu adalah Raja Louis VII dari Prancis dan Kaisar Konrad dari Jerman.

3. Berlansung dari tahun (1189-1192). Berawal dari kekalahan tentara salib di Tiberias oleh Sultan Saladin. Dalam perang ini, kaum salib dipimpin oleh Kaisar Friedrich III dari Jerman dan Barbarossa, Raja Richard dari Inggeris. Raja Richard berhasil menguasai daerah pesisir dan merebut kota Akko kemudian mengikat perjanjian dengan Sultan Saladin yang berisi kebebasan peziarah untuk berkunjung ke Yerusalem. ${ }^{11}$

${ }^{8}$ Harun Nasution, Pembaharuan Dalam Islam; Sejarah Pemikiran dan Gerakan (Jakarta: Buan Bintang, 1975), h. 13-14.

${ }^{9}$ Ajib Thohir, Perkembangan Peradan di Kawasan Dunis Islam, Melacak Akar-Akar Sejarah, Sosial, Politik dan Budaya Umat Islam (Jakarta: PT. Raja Grafindo Persada, 2004), h. 50-51; Ajib Thohir, Perkembangan Peradaban Islam di Kawasan Dunia Islam (Cet. I; Semarang: Dina Utama, 1997), h. 19.

${ }^{10}$ Karen Amstron, Perang Suci dari Perang Salib hingga Perang Teluk, terjemaahan Hikayat Darmawan, (Jakarta: Serambi, 2003), h. 27

${ }^{11}$ Carol Hillenbrand, Perang Salib Sudut Pandang Islam, terjemahan Hariadi, (Jakarta: serambi, 2005),h. 34-35. 
4. Berlansung pada tahun (1202-1204) berawal dari keinginan Paus Innocentius untutk menguasai Mesir dengan mengirim tentara ke Eropa Barat. Namun pada kenyataannya, tentara tersebut tidak pernah tiba di Mesir, malah tentara tersebut menduduki Venesia dan Konstantinopel serta memaksa mereka untuk tunduk kepada gereja Roma. ${ }^{12}$

5. Berlansung pada tahun (1218-1221) Pasca wafatnya Paus Innocentius III, penerusnya Honorius melanjutkan usaha untuk menguasai Mesir dan membuahkan hasil dengan menduduki kota Damietta sebuah daerah pantai di Mesir pada tahun 1221.

6. Berlansung pada tahun (1248-1245) Tahun 1244 Yerusalem kembali diduduki oleh tentara Islam dan akibat dari pendudukan ini, Raja Louis IX dari Prancis melakukan perang salib dan menyerang Mesir. Kerakusan Raja Luois untuk menguasai Mesir tak membuahkan hasil bahkan ia sendiri tertawan oleh tentara Islam dan dapat bebas setelah ditebus dengan bayaran yang sangat mahal higga kemudian ia kembali ke Prancis.

7. Berlansung pada tahun (1270). Sultan Bybars keturunan bangsa Mameluk dari Mesir berhasil mengakhiri perang ini secara gemilang dengan menguasai seluruh kekuatan dan kekuasaan tentara salib secara berturut-turut menguasai kota Jaffa dan Antiokhia pada tahun 1286, Tripoli dan Lebanon tahun 1289,Kota Akko sebagai kota terpenting kaum salib juga direbutnya pada tahun 1291. Sejak itulah kekuatan tentara salib sudah tidak ada lagi sekaligus mengakhiri perang salib yang terjadi selama 7 periode. $^{13}$

Meski perang salib telah selesai pengaruh buruk dan pencitraan buruk terhadap kaum muslimin oleh Kristen masih terus berlansung. Diantara bentuk pencitraan buruk tersebut adalah penyajian kaum muslimin dan Nabi Muhammad saw. sebagai penentang ajaran Nabi Isa as. Selajutnya agama Islam diidentikkan sebagai agama pedang yang disebarluaskan dengan kekerasan. Dalam pandangan William Montgomery Watt, distorsi penggambaran Islam sebagai agama pedang tidak berhenti bahkan terus menerus terjadi hingga kurun waktu abad ke XIX. ${ }^{14}$

Meski kalah dalam perang salib, kaum Kristen Barat banyak mengambil manfaat dari perseteruan ini. Mereka (kaum Kristen Barat) tidak akan mengenal peradaban modern yang mereka alami sekarang jika tidak terlibat dalam perang salib. Mereka membawa pulang ilmu-ilmu tentang pendirian rumah sakit, ilmu kedokteran modern, tempat mandi umum, buku-buku astronomi, geometri, sastra, peralatan, navigasi dan berbagai pengetahuan lain yang menopang peradaban moderen mereka. ${ }^{15}$

Perang salib telah memberi manfaat lansung kepada Kristen dalam upaya penerjemahan kitab-kitab kedokteran, filsafat, kesusateraan dan agama. Proses ini kemudian melahirkan pencerahan ilmu renaissance dalam bentuk penerjemahan kembali buku-buku berbahasa Arab ke dalam Bahasa Latin. ${ }^{16}$

\footnotetext{
${ }^{12}$ Carol Hillenbrand, Perang Salib Sudut Pandang Islam, h. 36

${ }^{13}$ Karen Amstron, Perang Suci dari Perang Salib hingga Perang Teluk, h. 28.

${ }^{14}$ William Montgomery Watt. Islam dan Peradaban Dunia, Pengaruh Islam atas Eropa Abad Pertengahan, (Bandung: Mizan, 2002), h. 68-69.

${ }^{15}$ Ismail al-Farūqī dan Lois Lamyā, Atlas Budaya Islam, terjemahan Ilyas Hasan, (Bandung: Mizan, 2001), h. 289-299.

${ }^{16}$ Ismail al-Farūqī dan Lois Lamyā, Atlas Budaya Islam, h. 289-299
} 
Perang salib telah melahirkan persentuhan budaya Barat yang saat itu masih dalam masa kegelapan dengan kebudayaan Islam yang telah memasuki masa kecemerlangan. Pertemuan ini telah banyak menguntungkan bangsa Barat dalam berbagai aspek semisal; kebudayaan, seni, perdagangan dan industri. Pada sisi lain muncul paradigma baru sebagai akibat perang salib yaitu hubungan dagang antara daerah-daerah Islam dengan daerah Kristen. ${ }^{17}$

\section{Hubungan Islam-Kristen Pada Masa Moderen}

Perang salib telah memberi angin segar terhadap dunia Barat dalam berbagai hal. Fakta paling mendasar dari pernyataan di atas adalah kemajuan dunia Barat yang cukup signifikan pada lapangan ilmu pengetahuan. Ilmu pengetahuan pada masa ini telah menjadi komoditi utama bangsa Barat dalam mengembangkan peradaban dan dunia militer. Lewat jalur kekuatan militer, bangsa Barat mampu mengadakan penetrasi yang cukup dalam terhadap daerah strategis umat Islam. Salah satu fakta tersebut adalah kehadiran Napolen Bonaparte di Mesir sebagai kelompok ekspedisi dengan menyertakan puluhan anggota dari berbagai disiplin keahlian yang berbeda-beda. ${ }^{18}$ Dalam kondisi ini, kaum muslimin menyadari bahwa bangsa Barat telah mencapai peradaban baru yang lebih maju dan meninggalkan mereka dalam keter belakangan.

Menurunnya hegemoni kaum muslimin disebabkan oleh ulah kaum muslimin sendiri yang cenderung suka hidup menyendiri dan lepas dari kelompok (jamā'ah). Pada sisi lain, gempuran tentara Mongol terhadap kota Bagdad telah melululantakkan peradaban Islam yang maju menjadi sebuah peradaban kelam lagi terkebelakang. Dampak berkepanjangan dari penyerbuan tentara Mongol ke Bagdad telah menghilangkan jembatan emas kaum muslimin dalam kajian keilmuan. Hal inilah yang mejadi penyebab pokok kemunduran umat Islam pada masa pertengahan. ${ }^{19}$ Pada sisi lain, kaum Salib telah mendapatkan jatidiri mereka dalam kajian ilmiyah dan jadilah mereka tumbuh dan berkembang menjadi suku penguasa.

Setidaknya ada 3 fase dalam ilmu Sejarah yang menggambarkan hubungan antara peradaban Kristen (Barat) dengan Islam (Timur), fase-fase tersebut dapat diurai sebagai berikut:

1. Fase Awal; Yakni fase dimana Islam memberikan sumbangan besar dalam bentuk kebudayaan kepada Barat (Kristen). Islam telah menjadi pandangan hidup baru setelah datangnya Nabi Muhammad saw. dan disebarluaskan secara cepat oleh para sahabat serta dinasti-dinasti Islam sesudahnya. Dalam kurun waktu abad ke 7 sampai abad ke 15, kedua dinasti ini mampu menerangi Eropa yang kala itu masih berada dalam era kegelapan (the dark age). Khalifah Abbasiyah merupakan dinasti yang paling terbuka dengan peradaban lainnya. Pertemua peradaban Islam-Barat di Spanyol telah memberi warna tersendiri dalam interaksi peradaban Islam klasik dalam bidang keilmuan dan keagamaan. Penyebaran buadaya Islam di Barat diprakarsai oleh raja Frederick dalam bentuk kontribusi terhadap manuskripmanuskrip Arab-Islam ke universitas terkenal di dunia saat ini yakni Oxford University serta University of Paris.

\footnotetext{
${ }^{17}$ William Montgomery Watt. Islam dan Peradaban Dunia, h. 68-69.

${ }^{18}$ Abū Hasan al-Nadwi, Islam Membangun Peradaban Dunia, (Jakarta: Pustaka Jaya, 1988), h.

${ }^{19}$ Abū Hasan al-Nadwi, Islam Membangun Peradaban Dunia, h. 221.
} 
2. Fase perjalanan hubungan Islam dengan barat yang diawali dengan invasi sebagaimana apa yang dilakukan oleh Prancis terhadap Mesir pada abad ke-18. Pada fase ini persentuhan budaya Barat-Islam tidak memberi kontribusi berarti bagi dunia Islam sebab pada fase ini kecenderungan Barat mendatangi Timur adalah untuk menjajah dan mencari rempah-rempah. Kedatangan Napoleon di Mesir hanya memberi manfaat pada laporan-laporan mereka yang dibuat dalam bentuk jurnal yang akan memberi banyak ilmu bagi kalangan terdidik yang akan menekuni studi kemesiran.

3. Fase Modernisasi; ditandai dengan gelombang besar arus revolusi humanism yang melanda Eropa dan beberapa Negara Islam. Dalam fase ini kaum muslimin terbagi menjadi dua bagian besar yaitu; bagian yang mengadopsi peradaban Barat secara keseluruhan tanpa proses pencocokan dengan budaya mereka dan kedua adalah golongan muslimin yang mengadakan filterisasi dan standarisasi nilai terhadap budaya Barat dan berusaha untuk memadukan kedua peradaban tersebut menjadi aspek utama pembentuk peradaban baru mereka. ${ }^{20}$

Berbicara tentang hubungan Islam-Kristen modern tidaklah mungkin terlepas dari Nostra Aetate sebuah dokumen Konsili Vatikan yang berisi upaya keterbukaan Kristen Katolik dalam membuka dialog antar umat beragama. Nostra Aetate pada pokoknya berisi tentang; 1). Eksistensi hidup bersama yang sudah selayaknya dibangun atas dasar ketulusan hati untuk saling memahami, 2). Proyek bersama terkait realita hidup antar umat beragama dalam kehidupan nyata sebagaimana terdapat dalam hal keadilan social, moralitas, perdamaian dan kebebasan. ${ }^{21}$ Isi piagam ini seolah-olah ingin mengubur sedalam-dalamnya endam kesumat permusuhan antar agama dan membangun paradigm baru dalam hubungan antar agama denga meletakkan dialog antar-agama pada posisi strategis untuk mencapai tujuan dan kedamaian bersama.

Nostra Aetate yang merupakan titik kulminasi tertinggi dari upaya-upaya rekonsiliasi antar-agama tidaklah sekonyong-konyong terjadi. Deretan upaya pihak gereja untuk mengarah kepada terciptanya dialog telah dirintis oleh mereka dan diantara fakta pembenaran terhada upaya tersebut adalah sebagai berikut; Manuel Paleologos (1350-1425) telah menulis banyak hal tentang Islam secara penuh hormat dan menjelaskan akar keterhubungan antara budaya Islam-Kristen di Barat. Petrus Venerabilis (1092-1156) yang telah memerintahkan untuk menerjemahkan Alquran ke dalam bahasa Latin dan terus menggerakkan upaya perbaikan dalam dialog antaragama, Ramon Liull (1233-1315) telah menempuh berbagaincara untuk membuka upaya dialog dengan kaum muslimin, Nicholas Cusanus (1401-1464) yang telah memberi komentar berbahasa Latin terhadap Alquran serta mencari hubungan baik yang mungkin terjadi antara umat Islam dengan umat Kristiani. ${ }^{22}$

Fase dialog antar-agama telah mengalami perbaikan terutama pada abad ke XX dimana Griffith menyebut dua orang penulis terkemuka saat itu yakni Kenneth Cragg (1913) dan Louis Massignon (1883-1962) yang belajar bahasa Arab dan sungguh

\footnotetext{
${ }^{20}$ Samuel P. Huntington, The Clash of Civilisation and The Remaking of Word Order (New York: Touchtone, 1998), h. 24.

${ }^{21}$ J. Bakker, SJ. Piagam Nostra Aetate Konsili Vatikan II: Tafsiran Zaman Kita, Zaman Dialog Antar-Agama, (Jogjakarta: Kanisius, 1972), h. 19.

${ }^{22}$ In Nugroho Budisantoso, Hubungan Kristen-Islam Pasca Tragedi WTC Dalam Perspektif Nostra Aetate, dalam Jurnal Orientasi Baru, Vol. 15 No. 1-2 Oktober 2006, h. 32.
} 
terkesan dengan keteraturan hidup kaum muslimin yang berada di kota Kairo dan sempat tertarik dengan seorang figure Sufi terkenal al-Hallāj (922). Begitupula dalam kajian kesusastraan Massignon menjalin kerjasama dengan Charles Foucald seorang pertapa di kawasan Muslimin Afrika Utara. Mereka berdua kemudian mendirikan sebuah persekutuan doa bersama yang dalam bahasa Arab dikenal dengan nama alBadaliyya. Persekutuan ini menyediakan ruang untuk berdoa dan berpuasa bagi kaum muslimin. Di antara anggota ternama dari persekutuan ini adalah Giovanni Batista Montini (Paus Paulus VI). ${ }^{23}$

Tampak jelas arah pandangan kaum misionaris Kristen untuk melakukan pendalaman agama lewat media dialog antar-agama. Setidaknya pada masa moderen seperti sekarang ini jalur dialog merupakan solusi yang tepat mengisi kekosongan dan kesenjangan antara Islam-Kristen. Sebuah upaya yang menyisakan banyak tenaga untuk berfikir jernih dan kontemplatif memecahkan masalah kebuntuan hubungan IslamKristen.

Perjalanan lewat laut oleh bangsa Portugis dan Spanyol telah mengantarkan mereka ke Negara timur Asia Tenggara meliputi Malaka hingga Indonesia. Kehadiran Portugis di Malaka telah merubah konstalasi sejarah Umat Islam di daerah ini dengan memaksa mereka secara senjata untuk memeluk agama Kristen. Misi kedatangan Portugis di Malaka tak terlepas dari 3 misi utama mereka yakni; Glory, Gold dan Gosfel. Kondisi yang hampir serupa juga dialami oleh orang-orang Ternate di Indonesia. Upaya untuk menguasai Ternate mendapat perlawanan yang sengit dari masyarakat Islam setempat dalam kesultanan Ternate. Sultan Hairun (1550-1570) merupakan pencetus pertama pertentangan tersebut dan terus menerus terjadi hingga Sultan Baabullah (1570-1583) yang mampu menyatukan kesultanan Tidore dan Ternate dalam sebuah kesultanan untuk melawan penjajah Portugis. Sultan Baabullah berhasil mengusir penjajah dari bumi Ternate yang kemudian menyebabkan orang-orang Portugis bermigrasi ke Ambon. Meski kemudian mereka tidak disenangi dan akhirnya diusir dari wilayah Ambon, namun orang-orang Portugis berhasil menyebarkan agama Kristen di Ambon dengan mendirikan persekutuan umat Katolik di daerah ini. ${ }^{24}$

Penyebaran agama Kristen yang dilakukan oleh Portugis terhadap wilayahwilayah timur Nusantara sangat kontra produktif dengan semangat dialog antar-agama yang dilakuka oleh pendahulu-pendahulu Kristen Katolik yang menginginkan terciptanya suasana nyaman antar penganut agama. Motivasi penjajahan dan perebutan sumber hasil bumi merupakan landasan utama kedatangan mereka, disamping upaya penyebaran agama. Ini pulalah yang kemudian membuat kedatangan orang-orang Belanda yang beragama Protestan, cenderung melarang penyebaran agama Katolik. Agama Kristen Protestan adalah agama resmi Negara di Belanda dan pada tahun 1605, orang Belanda telah berhasil merebut benteng "Victoria" milik Portugis di Ambon. ${ }^{25}$

Sikap Belanda yang netral dalam urusan agama berbanding terbalik dengan sikap mereka terhadap kaum Muslimin. Bagi orang Belanda, oranmg-orang muslim

\footnotetext{
${ }^{23}$ In Nugroho Budisantoso, Hubungan Kristen-Islam Pasca Tragedi WTC Dalam Perspektif Nostra Aetate, dalam Jurnal Orientasi Baru, Vol. 15 No. 1-2 Oktober 2006, h. 33.

${ }^{24}$ Kees De Jong, Dari Perpisahan Kolonial ke Perjuangan Nasional Bersama, dalam Gema Teologi, Vol. 36 No. 2, Oktober 2012, h. 236.

${ }^{25}$ Kees De Jong, Dari Perpisahan Kolonial ke Perjuangan Nasional Bersama, dalam Gema Teologi, Vol. 36 No. 2, Oktober 2012, h. 237
} 
adalah orang orang-orag yang tak dapat mereka percayai. Inilah yang kemudian memicu salah seorang pemimpin mereka yaitu JP. Coen dalam memorandumnya tanggal 1 Januari 1614 menetapkan orang-orang muslim sebagai musuh mereka dan mereka wajib dihancurkan. ${ }^{26}$ Standarisasi ganda telah diberlakukan denga memberi prioritas atas para pekerja VOC yang Bergama Kristen Protestan dibandingkan para pekerja berkebangsaan Belanda di Maluku. ${ }^{27}$

Tahun 1799 VOC bangkrut dan Negara Belanda kemudian mengambil alih seluruh asset VOC hingga tahun 1811 ketika belanda dalam penguasaan Napoleon Bonaparte. Ketika itupula, Inggris ditetapkan sebagai penguasa atas wilayah jajahan Belanda di Indonesia di bawah kekuasaan Sir Thomas Stamford Raffles (1811-1816). Kebijakan Inggris rupanya sangat berbeda dengan Belanda, letak perbedaan itu adalah adanya izin untuk kelompok Baptis Missionary Society and London Missionary Society untuk mengadakan penyebaran agama di Jawa. ${ }^{28}$ Meski demikian, hasil dari izin bagi dua kelompok misionaris tadi tidak membuahkan hasil yang signifikan.

Tahun 1853 terjadi perubahan mendasar di Belanda dengan pemulihan hak kaum Katolik dalam hierarki hukum Belanda, agama Katolik kembali mendapat tempat unuk disebarkan pada Negara jajahan. Missionaris dan Zending akhirnya berebut kekuasaan pula dalam penyebaran agama dan menimbulkan kekisruhan baru pada daerah jajahan. Selanjutnya, pemerintah colonial Belanda mengambil sikap untuk membatas keduanya dengan permintaan izin terlebih dahulu kepada pemerintah. Kehadiran kedua perutusan secara bersamaan dibatasi sehingga perebutan tidak terjadi, demikian pula halnya pada daerah dimana agama Islam sangat kuta pengaruhnya, maka zending maupun misionaris tidak diperkenankan untuk hadir. ${ }^{29}$

Pembagian warga Negara dalam tiga kelompok besar yaitu; Orang Eropa yang secara keseluruhan mengikuti hukum Belanda, Orang Tionghoa dan Arab diwajibkan untuk meminta izin perjalanan jika akan melakukan perjalanan ke luar kota dan bagi mereka berlaku hukum Belanda; serta Pribumi yang mengikuti aturan agama mereka. ${ }^{30}$ Pengelompokan ini membuat kebijakan hukum Belanda semakin bias, bahkan pernah terjadi seorang pegawai Belanda menendang seorang warga pribumi Jawa. Persoalan ini kemudian diajukan ke meja hijau dan terjadilah peradilan yang tidak berimbang. Dalam peradilan ini keseimbangan hukum dalam pidana tidak terjadi dan membuat pegawai Belanda tadi dapat bebas dari jeratan hukum pidana, meskipun hukum Belanda menganut azas persamaan hak di depan hukum. ${ }^{31}$

Tahun 1900-1942 arah kebijakan politik Hindia-Belanda mengalami perubahan menjadi politik "Etis". Arah kebijakan politik ini sudah mulai mempehatikan nasib orag

\footnotetext{
${ }^{26}$ Kees De Jong, Dari Perpisahan Kolonial ke Perjuangan Nasional Bersama, dalam Gema Teologi, Vol. 36 No. 2, Oktober 2012, h. 237

${ }^{27}$ Kees De Jong, Dari Perpisahan Kolonial ke Perjuangan Nasional Bersama, dalam Gema Teologi, Vol. 36 No. 2, Oktober 2012, h. 237

${ }^{28}$ Kees De Jong, Dari Perpisahan Kolonial ke Perjuangan Nasional Bersama, dalam Gema Teologi, Vol. 36 No. 2, Oktober 2012, h. 238

${ }^{29}$ Kees De Jong, Dari Perpisahan Kolonial ke Perjuangan Nasional Bersama, dalam Gema Teologi, Vol. 36 No. 2, Oktober 2012, h. 240.

${ }^{30}$ Kees De Jong, Dari Perpisahan Kolonial ke Perjuangan Nasional Bersama, dalam Gema Teologi, Vol. 36 No. 2, Oktober 2012, h. 240

${ }^{31}$ Kees De Jong, Dari Perpisahan Kolonial ke Perjuangan Nasional Bersama, dalam Gema Teologi, Vol. 36 No. 2, Oktober 2012, h. 240
} 
Subehan Khalik

pribumi. Tokoh berpengaruh terhadap kebijakan ini adalah Snouck Hurgronje yang berkedudukan sebagai penasehat pemerintah Hindia-Belanda dalam urusan keagamaan dan persentuhan pemerintah dengan golongan pribumi yang mayoritas muslim. Arah kebijakan ini tak terduga karena banyak melahirkan gerakan terpelajar dalam mengorganisir warga pribumi. Gerakan terstruktur dalam komunitas tertutup tidak disadari oleh pemerintah Hindia Belanda karena mereka memberlaku kan sekat hukum yang ketat. Maka tak heran jika pada akhirnya kekuasaan Belanda mampu diusir dari Indonesia lewat gerakan terpelajar dan pemberontakan lainnya sampai kemudian pemerintahan Jepang datang ke Indonesia.

Masa pemerintahan Jepang tidak juga mengakhiri ketimpangan atas perlakuan pribumi yang beragama Islam, namun tidak sekejam apa yang berlaku pada masa pemerintahan kolonial Belanda. Jepang mengakui segala macam bentuk organisasi terpelajar penduduk pribumi dan organisasi politik yang mulai banyak terlahir. Di antara organisasi politik yang diakui dan dapat menjadi organisasi militer adalah organisasi Masyumi. ${ }^{32}$ Pada akhirnya Jepang lah yang memberi kontribusi besar dalam gerakan terpelajar pribumi di Indonesia untuk memproklamirkan kemerdekaan pada tahun 1945, meski Jepang sendiri tidak mendukung kearah kemerdekaan itu. Tanggal 18 Agustus 1945 Soekarno mengesahkan dasar Negara dengan "ketuhanan yang Maha Esa" sebagai sila pertama setelah melewati diskusi panjang dengan kaum nasionalis Kristen dan Hindu setelah menghapus konsep awal piagam Jakarta "dengan kewajiban menjalankan syariat Islam bagi pemeluk-pemeluknya". ${ }^{33}$

${ }^{32}$ Kees De Jong, Dari Perpisahan Kolonial ke Perjuangan Nasional Bersama, dalam Gema Teologi, Vol. 36 No. 2, Oktober 2012, h. 245.

${ }^{33}$ Kees De Jong, Dari Perpisahan Kolonial ke Perjuangan Nasional Bersama, dalam Gema Teologi, Vol. 36 No. 2, Oktober 2012, h. 245. 


\section{KESIMPULAN}

1. Akar masalah antara pertemuan Islam-Kristen adalah kekhawatiran kaum Kristen terhadap penyebaran agama Islam yang sangat massif dan luas, melahirkan kecemburuan dan kekhawatiran penganut Kristen untuk membatasi dan melawan perluasan tersebut. Pada sisi lain teologi Islam yang mengajarkan bahwa agama Kristen telah mengalami perubahan dan kedatangan Islam sebagai agama penyempurna dari ajaran tersebut, menjadi pupuk yang menghidup suburkan sekat antara kedua agama ini. Pada akhirnya kedua agama ini harus berhadapan dalam sebuah krisis kemanusiaan tiada tara yang bernama "perang Salib"

2. Pertemua Islam-Kristen pada masa pertengahan lebih dominan diwarnai dengan konflik bersenjata perang salib. Silih berganti kedua agama ini saling menyerang dan menghabiskan banyak dana dan sumber daya terbaik kedua agama ini. Putera-putera terbaik kedua agama ini harus meregang nyawa di medan pertempuran. Hal ini menyebabkan terciptanya kesetaraan baru dalam dunia peradaban di mana peradaban Eropa yang masih gelap gulita terjalin dengan apik dengan peradaban Islam yang telah mencapai puncak kejayaan. Hasilnya kemudian memberi manfaat besar terhadap kaum Kristen, meski mereka telah mengalami kekalahan telak dalam pertempuran yang memakan waktu hampir dua abad.

3. Pasca perang Salib pergulatan antara Islam-Kristen tidak juga berhenti karena bangsa Barat yang telah memasuki babak baru peradaban maju kemudian mulai mencaplok daerah-daerah Timur yang mayoritas beragama Islam. Umat Islam kala itu sedang mengalami masa kegelapan sebagai akibat dari perpecahan kaum muslimin dan ketidak mampuan mereka menahan serangan Mongol pada masa selanjutnya. Daerah-daerah Islam mulai dijajah dalam bentuk politik kolonilisme dan Imprealisme oleh Portugis, Spanyol dan Belanda. Sementara di semenanjung Afrika, kehadiran Prancis sangat kontras lewat perlawatan Napolen Bonaparte ke beberapa Negara muslim semisal Mesir. Konteks ini memberi corak bahwa Islam telah mengalami keterpurukan dalam peradaban dan akses terhadap tekhnologi maju, sampai kepada Indonesia.

\section{DAFTAR PUSTAKA}

al-Farūq̄ị, Ismail dan Lois Lamyā, Atlas Budaya Islam, terjemahan Ilyas Hasan. Bandung: Mizan, 2001.

al-Mubarakfīrī, Șafiyyu al-Raḥmān. Sirah Nabawiyah, Terjemahan Kathur Suhardi. Jakarta: Pustaka al-Kaustar, 1997.

al-Nadwi, Abū Hasan. Islam Membangun Peradaban Dunia. Jakarta: Pustaka Jaya, 1988.

Amstron, Karen. Perang Suci dari Perang Salib hingga Perang Teluk, terjemaahan Hikayat Darmawan. Jakarta: Serambi, 2003.

Azra, Azyumardi. Memahami Konflik barat-Islam dalam Era Globalisasi, Pengantar dalam Buku Karel Strenbrink, Kawan Dalam Pertikaian, Kaum Kolonial Belanda dan Islam di Indonesia. Bandung: Mizan, 1995. 
Pergolakan Politik Islam: Dari Fundamentalisme, Modernisme hingga Post-Modernisme. Jakarta: Paramadina, 1996.

Budisantoso, In Nugroho. Hubungan Kristen-Islam Pasca Tragedi WTC Dalam Perspektif Nostra Aetate, dalam Jurnal Orientasi Baru, Vol. 15 No. 1-2 Oktober 2006.

De Jong, Kees. Dari Perpisahan Kolonial ke Perjuangan Nasional Bersama, dalam Gema Teologi, Vol. 36 No. 2, Oktober 2012

Hillenbrand, Carol. Perang Salib Sudut Pandang Islam, terjemahan Hariadi. Jakarta: serambi, 2005.

L. Esposito, John. Bahaya Hijau, Alihbahasa Sunarto. Jogjakarta: Pustaka Pelajar, 1997.

M. Sewang, Ahmad. Islamisasi Kerajaan Gowa; Abad XVI sampai Abad XVII. Jakarta: Yayasan Obor Indonesia, 2005.

Nasution, Harun Pembaharuan Dalam Islam; Sejarah Pemikiran dan Gerakan. Jakarta: Buan Bintang, 1975.

P. Huntington, Samuel. The Clash of Civilisation and The Remaking of Word Order. New York: Touchtone, 1998.

SJ. J. Bakker, Piagam Nostra Aetate Konsili Vatikan II: Tafsiran Zaman Kita, Zaman Dialog Antar-Agama. Jogjakarta: Kanisius, 1972.

Thohir, Ajib. Perkembangan Peradaban Islam di Kawasan Dunia Islam. Cet. I; Semarang: Dina Utama, 1997.

Thohir, Ajib. Perkembangan Peradan di Kawasan Dunis Islam, Melacak Akar-Akar Sejarah, Sosial, Politik dan Budaya Umat Islam. Jakarta: PT. Raja Grafindo Persada, 2004.

Tim Penyusun IAIN Syarif Hidayatullah, Ensiklopedia Islam. Jakarta: Djambatan, 1992.

Wajd̄̄, Muhammad Fārid. Da'irah al-Ma'ārif al-Qarn al-'Isyrīn, Jilid V. Beyrīt: Dār al-Fikr, t.t.

Watt. William Montgomery. Islam dan Peradaban Dunia, Pengaruh Islam atas Eropa Abad Pertengahan. Bandung: Mizan, 2002.

Yatim, Badri. "Dari Mekkah ke Madinah" Dalam Taufik Abdullah dan Din Syamsuddin (ed), Ensiklopedia Tematis Dunia Islam, jilid II. Jakarta: PT. Ichtiar Van Hoeve, t.t. 